\title{
The Effect of Hydrogen Peroxide on Spores of Clostridium bifermentans
}

\author{
By CATHERINE E. BAYLISS AND W. M. WAITES \\ Agricultural Research Council Food Research Institute, \\ Colney Lane, Norwich NR4 7 UA
}

(Received I4 May 1976)

\begin{abstract}
SUMMARY
The effect of hydrogen peroxide on the germination, colony formation and structure of spores of Clostridium bifermentans was examined. Treatment with $0.35 \mathrm{M}$-hydrogen peroxide increased the germination rate at $25{ }^{\circ} \mathrm{C}$ but increasing the temperature or concentration of hydrogen peroxide decreased both the germination rate and colony formation. The presence of $\mathrm{Cu}^{2+}$ increased the lethal effect of hydrogen peroxide on colony formation as much as 3000-fold. Preincubation of spores with $\mathrm{Cu}^{2+}$ before treatment with hydrogen peroxide produced a similar increase, but this could be eliminated by washing the spores with dilute acid or ethylenediamine tetraacetate. Hydrogen peroxide removed protein from spores-apparently from the coat-and treatment with dithiothreitol, which also removes spore-coat protein, increased the lethal effect of hydrogen peroxide 500fold, suggesting that spore-coat protein has a protective effect against hydrogen peroxide.
\end{abstract}

\section{INTRODUCTION}

Hydrogen peroxide rapidly kills vegetative bacteria (Dittmar, Baldwin \& Miller, 1930) but bacterial spores are much more resistant (for a review, see Roberts \& Hitchins, 1969) although the reasons for this are not understood. Most previous studies on spores have been confined to the effect of hydrogen peroxide on colony-forming ability. Curran, Evans \& Leviton (1940) first showed that the rate of loss of viability of spores in the presence of hydrogen peroxide depends on temperature and $\mathrm{pH}$. Copper and cobalt ions increase the lysis of spores by hydrogen peroxide (Gould \& Hitchins, 1963) but their effect on spore viability and structure has not been examined. We have therefore studied the effect of $\mathrm{pH}$, temperature and the concentration of hydrogen peroxide and metal ions on colony formation, germination and the structure of spores of Clostridium bifermentans.

\section{METHODS}

Organism, spore preparation and maintenance of culture. The strain of Clostridium bifermentans used and the preparation and storage of spores were as described previously (Waites \& Wyatt, 1971) except that spores were produced on a trypticase agar containing $\left(\mathrm{g}^{-1}\right)$ : Trypticase (BBL), 30; yeast extract (Difco), I•0; ammonium sulphate, I0; agar, I2; adjusted to $\mathrm{pH} 7.3$ with $\mathrm{I} \mathrm{M}-\mathrm{NaOH}$. The organism was maintained in the reinforced clostridial medium of Hirsch \& Grinsted (I954).

Treatment of spores with hydrogen peroxide. Hydrogen peroxide (BDH) at the concentrations described was added to spores (about $0.7 \mathrm{mg}$ dry wt $\mathrm{ml}^{-1}$ ) in sodium phosphate buffer ( $100 \mathrm{~mm}$ in phosphate at the stated $\mathrm{pH}$ ) which had been pre-incubated at the required 
temperature in polypropylene centrifuge tubes. After incubation, the tubes were cooled rapidly in ice-water, the contents were diluted tenfold with glass-distilled water and centrifuged for $10 \mathrm{~min}$ at $15000 \mathrm{~g}$ and $4^{\circ} \mathrm{C}$, and the spores were washed twice with glass-distilled water by centrifugation at $4^{\circ} \mathrm{C}$.

Treatment with dithiothreitol. Spores $\left(0.7 \mathrm{mg}^{\mathrm{dry}} \mathrm{wt} \mathrm{ml}^{-1}\right)$ were incubated with Io $\mathrm{mm}$ dithiothreitol for $15 \mathrm{~min}$ at $\mathrm{pH} 10.5$ and $37^{\circ} \mathrm{C}$ (Aronson \& Fitz-James, 197I) and then washed twice with glass-distilled water.

Colony formation and germination. Colony formation was tested on reinforced clostridial medium solidified with $\mathrm{I} \cdot 2 \%(\mathrm{w} / \mathrm{v})$ agar as described previously (Waites \& Wyatt, $1974 a$ ). Germination was measured spectrophotometrically as described by Waites \& Wyatt (I97I). Germination media contained (mM): for the 'Ala +' system, L-alanine (50), L-arginine (5), L-phenylalanine (5), L-lactate (25), sodium chloride (100) and sodium phosphate buffer $\mathrm{pH}$ 7.5 ( $83 \mathrm{~mm}$ in phosphate); and for the 'Ala' system, L-alanine (50), sodium chloride (I00) and sodium phosphate buffer $\mathrm{pH} 8.0$ ( $83 \mathrm{~mm}$ in phosphate). Previously we have shown that the 'Ala +' system is optimal for spores produced on the reinforced clostridial medium agar of Hirsch \& Grinsted (1954) (Waites \& Wyatt, I974b). With the spores produced on the trypticase medium, the concentration of L-phenylalanine in the 'Ala +' system was slightly inhibitory; germination rates for treated and untreated spores were $7 \%$ and $15 \%$ less than the maximum, obtained with $3 \mathrm{mM}$ L-phenylalanine. As mild treatment with hydrogen peroxide caused spores to germinate optimally with the 'Ala' system, they sometimes germinated slightly faster with the 'Ala' system than with the 'Ala +' system.

Polyacrylamide gel electrophoresis of spore extracts. Extracts were made from $14 \mathrm{mg}$ dry

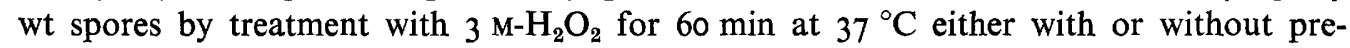
incubation with $100 \mu \mathrm{M}-\mathrm{CuSO}_{4}$. The suspension was centrifuged for $10 \mathrm{~min}$ at $15000 \mathrm{~g}$ and the supernatant was dialysed against glass-distilled water before concentration and addition of $\mathrm{NaOH}: 0.2 \mathrm{ml}$ containing $\mathrm{I} 00 \mu \mathrm{g}$ protein in $0 . \mathrm{I} \mathrm{M}-\mathrm{NaOH}$ and $10 \%(\mathrm{w} / \mathrm{v})$ sucrose was added to polyacrylamide gels. Electrophoresis was carried out as described by Davis \& Ornstein (196I), but without the overlayer of large-pore gel, in vertical columns for about $60 \mathrm{~min}$ at $5 \mathrm{~mA} / \mathrm{gel}$ and $4{ }^{\circ} \mathrm{C}$. Bromophenol blue $(0.00 \mathrm{I} \%$, w/v) was used as a marker and amido black $(\mathrm{I} \cdot 0 \%, \mathrm{w} / \mathrm{v})$ in acetic acid $(7 \%, \mathrm{v} / \mathrm{v})$ as a stain. Gels were destained with several changes of acetic acid $(7 \%, v / v)$ during $36 \mathrm{~h}$ at room temperature.

Spore dry weight. Dry weights were estimated spectrophotometrically. Extinction was measured at $600 \mathrm{~nm}$ and converted to spore dry weight using a standard calibration curve relating $E_{600}$ to spore weight.

Protein estimations. These were made by the method of Lowry et al. (195I) with bovine plasma albumin fraction V (Armour Pharmaceuticals, Eastbourne, Sussex) as a standard.

\section{RESULTS}

\section{Effect of $\mathrm{pH}$, temperature and hydrogen peroxide concentration on germination and colony formation}

When spores were treated with $\mathrm{I} \cdot 42 \mathrm{M}-\mathrm{H}_{2} \mathrm{O}_{2}$ at $25{ }^{\circ} \mathrm{C}$ for $30 \mathrm{~min}$ at different hydrogen-ion concentrations, those treated in sodium phosphate buffer $\mathrm{pH} 7.0$ (which gave a final $\mathrm{pH}$ of about 6.7) germinated most slowly with either the 'Ala +' or 'Ala' germination system (Fig. I). This suggested that the greatest lethal effect occurred at this $\mathrm{pH}$ and it was used for all subsequent treatments with $\mathrm{H}_{2} \mathrm{O}_{2}$. Treatment with different concentrations of $\mathrm{H}_{2} \mathrm{O}_{2}$ at $25^{\circ} \mathrm{C}$ for $30 \mathrm{~min}$ showed that the colony-forming ability was not reduced by up to $0.43 \mathrm{M}$ $\mathrm{H}_{2} \mathrm{O}_{2}$ but was markedly reduced by higher concentrations (Fig. 2). With the 'Ala' germin- 


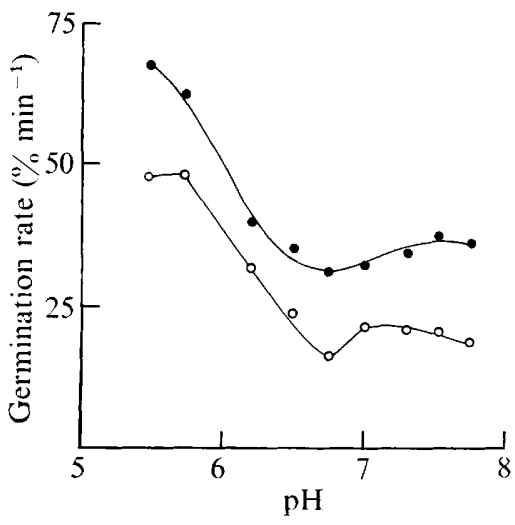

Fig. I

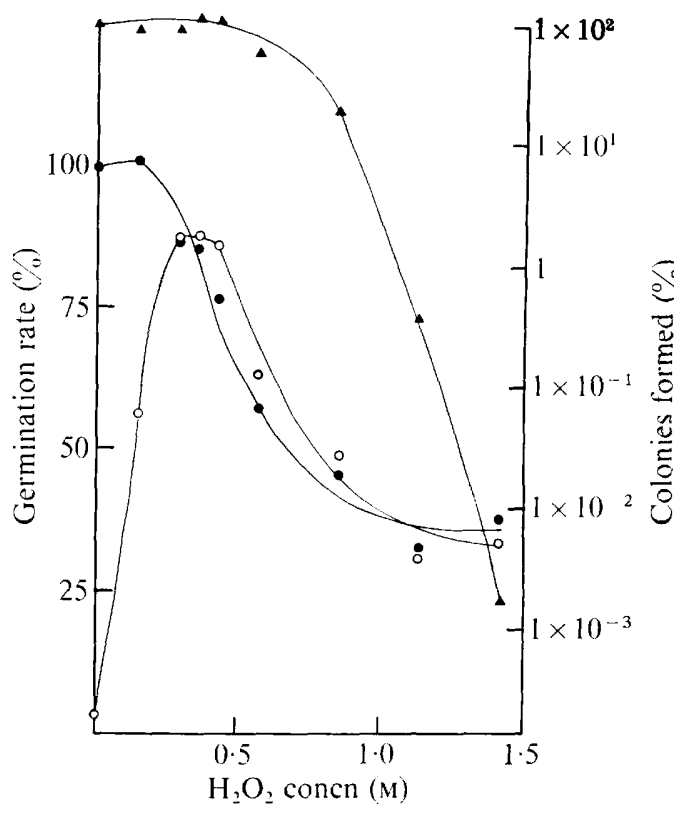

Fig. 2

Fig. 1. Effect of $\mathrm{H}_{2} \mathrm{O}_{2}$ at different hydrogen-ion concentrations on germination rate. Spores were treated with $\mathrm{I} \cdot 42 \mathrm{M}-\mathrm{H}_{2} \mathrm{O}_{2}$ at $25{ }^{\circ} \mathrm{C}$ for $30 \mathrm{~min}$, as described in Methods. After washing, the spores were germinated with the 'Ala + ' $(0)$ or 'Ala' $(O)$ systems. Germination rates for untreated spores were $109 \% \mathrm{~min}^{-1}$ ('Ala +' system) and $5.4 \% \mathrm{~min}^{-1}$ ('Ala' system).

Fig. 2. Effect of $\mathrm{H}_{2} \mathrm{O}_{2}$ concentration on colony-forming ability and germination. Spores in sodium phosphate buffer $\mathrm{pH} 77^{\circ} \mathrm{O}$ were treated with $\mathrm{H}_{2} \mathrm{O}_{2}$ at $25^{\circ} \mathrm{C}$ for $30 \mathrm{~min}$, as described in Methods. The percentage of spores able to form colonies $(\boldsymbol{\Delta})$ and the germination rates with 'Ala + ' $(\boldsymbol{O})$ and 'Ala' (O) germination systems are expressed as a percentage of the number of colonies formed and the germination rate (with 'Ala +'), respectively, of spores incubated in the absence of $\mathrm{H}_{2} \mathrm{O}_{2}$. Such spores formed $\mathrm{I} \cdot 04 \times 10^{9}$ colonies $\mathrm{ml}^{-1}$ and germinated at a rate of $84 \% \mathrm{~min}^{-1}$.

ation system the germination rate was increased 26 -fold by $0.35 \mathrm{M}-\mathrm{H}_{2} \mathrm{O}_{2}$, but with the 'Ala + ' system no increase in rate was detected. With $\mathrm{I} \cdot 42 \mathrm{M}-\mathrm{H}_{2} \mathrm{O}_{2}$ the germination rate with both systems was markedly reduced, but the decrease in turbidity during germination showed that about $80 \%$ of the spores germinated even though less than I in $10^{4}$ spores were able to form colonies.

Treatment with $\mathrm{I} \cdot 42 \mathrm{M}-\mathrm{H}_{2} \mathrm{O}_{2}$ at $25{ }^{\circ} \mathrm{C}$ required about $20 \mathrm{~min}$ for a $99 \%$ reduction in colony-forming ability and no kill occurred within the first $2.5 \mathrm{~min}$ (Fig. $3 a$ ). However, with $0.142 \mathrm{M}^{-} \mathrm{H}_{2} \mathrm{O}_{2}$ at $70^{\circ} \mathrm{C}$ less than $5 \mathrm{~min}$ was required for a $99 \%$ kill (Fig. $3 b$ ). After $6 \mathrm{~min}$ at $70^{\circ} \mathrm{C}$ there was little further decrease in colony formation, but the decrease resumed after $10 \mathrm{~min}$. This 'plateau' effect did not occur at $25^{\circ} \mathrm{C}$. The increased rate of kill after Io min at $70^{\circ} \mathrm{C}$ may therefore have been due to the effect of heat on spores damaged with hydrogen peroxide. Treatment at $25^{\circ} \mathrm{C}$ resulted, as before, in an initial increase in germination rate with the 'Ala' but not with the 'Ala +' system (Fig. $3 a$ ). Treatment at $70^{\circ} \mathrm{C}$ resulted in similar changes, but the rate decreased more rapidly than at $25^{\circ} \mathrm{C}$ and reached a lower level (Fig. $3 b$ ). 

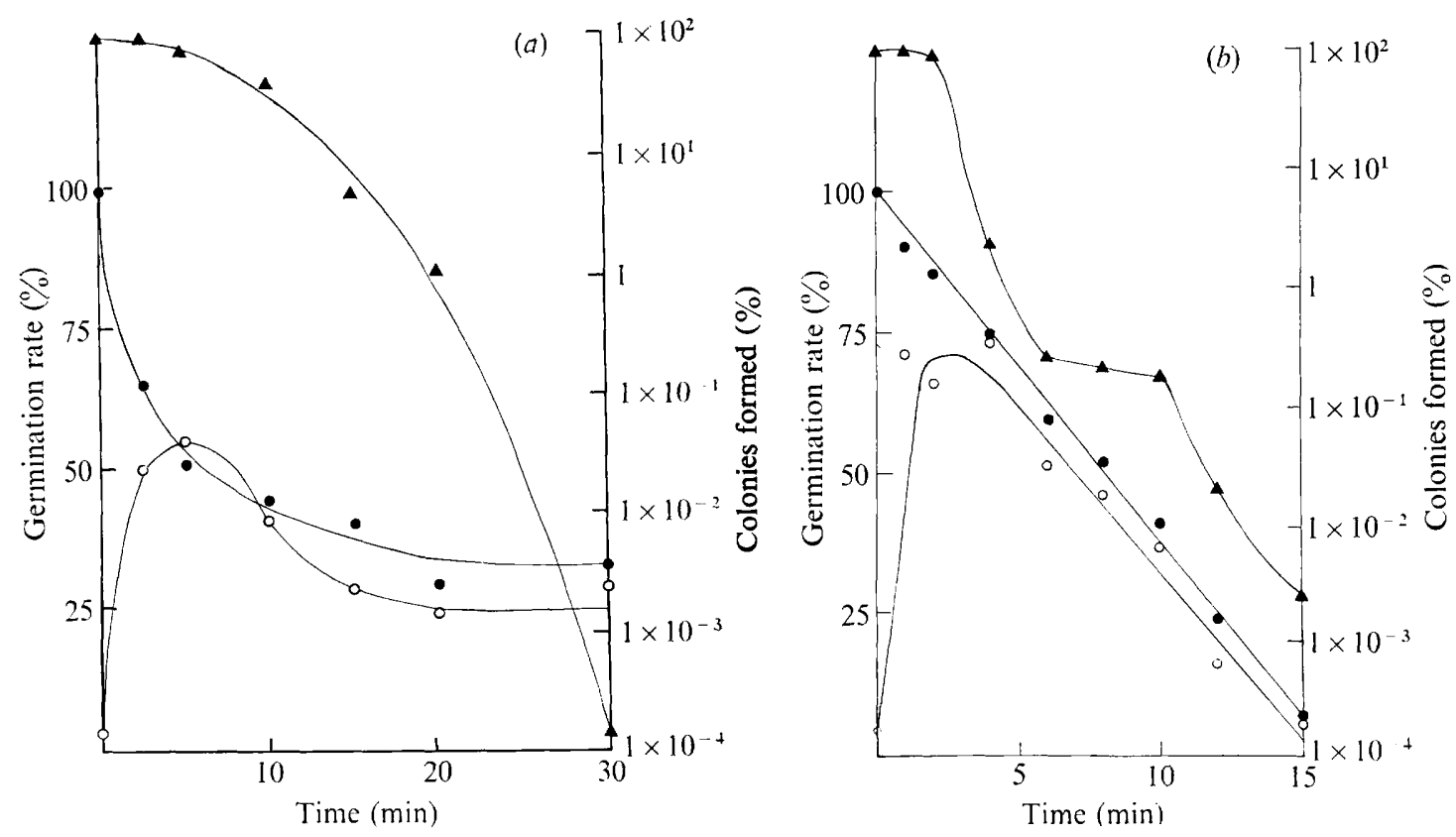

Fig. 3. Effect of $\mathrm{H}_{2} \mathrm{O}_{2}$ at $25^{\circ} \mathrm{C}$ and $70^{\circ} \mathrm{C}$ on germination rate and colony-forming ability. Spores were incubated, as for Fig. 2, either (a) with $1 \cdot 42 \mathrm{M}-\mathrm{H}_{2} \mathrm{O}_{2}$ at $25{ }^{\circ} \mathrm{C}$ or $\left(\right.$ b) with $0 \cdot 142 \mathrm{M}-\mathrm{H}_{2} \mathrm{O}_{2}$ at $70^{\circ} \mathrm{C}$. Samples were removed at intervals and the colony-forming ability $(\boldsymbol{\Delta})$ and germination rates with the 'Ala +' $(O)$ and 'Ala' $(O)$ germination systems were determined as described in Methods. Results are expressed as in Fig. 2. Unincubated spores formed $(a) 1 \cdot 2 \times 10^{9}$ and $(b)$ $9.7 \times 10^{8}$ colonies $\mathrm{ml}^{-1}$ and germinated at a rate of $(a) 86 \% \mathrm{~min}^{-1}$ and $(b) 118 \% \mathrm{~min}^{-1}$; spores incubated in the absence of $\mathrm{H}_{2} \mathrm{O}_{2}$ formed $(a) 9.5 \times 10^{8}$ and $(b) 9.4 \times 10^{8}$ colonies $\mathrm{ml}^{-1}$ and germinated at $(a) 80 \% \mathrm{~min}^{-1}$ and $(b) 95 \% \mathrm{~min}^{-1}$.

\section{Effect of hydrogen peroxide and metal ions on germination and colony formation}

Gould \& Hitchins (1963) showed that certain divalent metal ions increased the lysis of spores by $\mathrm{H}_{2} \mathrm{O}_{2}$. We therefore incubated spores with $100 \mu \mathrm{M}$ metal ions with or without $0.28 \mathrm{M}-\mathrm{H}_{2} \mathrm{O}_{2}$ for $30 \mathrm{~min}$ at $25^{\circ} \mathrm{C}$ (Table I). Metal ions alone had little effect on colony formation or germination but addition of $\mathrm{Cu}^{2+}$ to $\mathrm{H}_{2} \mathrm{O}_{2}$ markedly reduced both the number of colonies formed and the germination rate. Other metal ions were much less effective although $\mathrm{Fe}^{2+}$ in $\mathrm{H}_{2} \mathrm{O}_{2}$ slightly reduced the number of colonies formed. The lethal effect of $\mathrm{H}_{2} \mathrm{O}_{2}$ on subsequent colony formation was increased 4- and 28 -fold by pre-incubation for 5 min at $37{ }^{\circ} \mathrm{C}$ with 5 and $20 \mu \mathrm{M}-\mathrm{Cu}^{2+}$ respectively, and germination rates were also decreased although to a lesser extent (Fig. 4). Pre-incubation with $\mathrm{Cu}^{2+}$ for $2 \mathrm{~min}$ at $0{ }^{\circ} \mathrm{C}$ or I min at $37^{\circ} \mathrm{C}$ also markedly reduced the resistance to subsequent treatment with $\mathrm{H}_{2} \mathrm{O}_{2}$ and this suggested that $\mathrm{Cu}^{2+}$ was rapidly absorbed by the spores even at low temperature. However, washing the treated spores with $0.04 \mathrm{M}-\mathrm{HCl}$ (Table 2) or $250 \mu \mathrm{M}$-EDTA eliminated most of the effect of 5 or Io $\mu \mathrm{M}-\mathrm{Cu}^{2+}$, presumably by removing the $\mathrm{Cu}^{2+}$.

\section{Effect of hydrogen peroxide and $\mathrm{Cu}^{2+}$ on spore structure}

Treatment of spores with $\mathrm{H}_{2} \mathrm{O}_{2}$ in the presence or absence of $\mathrm{Cu}^{2+}$ removed protein which, on polyacrylamide gel electrophoresis, had a mobility similar to that of the protein removed from spore coats by chlorine (Wyatt \& Waites, 1975). Spores also lost refractility from their peripheries when treated successively with $10 \mu \mathrm{M}-\mathrm{Cu}^{2+}$ at $37^{\circ} \mathrm{C}$ for $5 \mathrm{~min}$ and $0.03 \mathrm{M}-\mathrm{H}_{2} \mathrm{O}_{2}$ 
Table I. Effect of divalent metal ions and hydrogen peroxide on spore viability and germination rate

Spores (0.7 mg dry wt $\mathrm{ml}^{-1}$ ) were incubated with or without $0.28 \mathrm{M}-\mathrm{H}_{2} \mathrm{O}_{2}$ and $100 \mu \mathrm{M}$ metal sulphates at $25^{\circ} \mathrm{C}$ for $30 \mathrm{~min}$ in sodium phosphate buffer ( $100 \mathrm{~mm}$ in phosphate) then cooled in ice-water, diluted tenfold with glass-distilled water, and washed twice with distilled water by centrifugation at $4{ }^{\circ} \mathrm{C}$. Colony formation and germination rate were determined as described in Methods. The values obtained for spores incubated with the 'Ala + ' system in the absence of $\mathrm{H}_{2} \mathrm{O}_{2}$ and metal ions are taken as $100 \%$. Such spores formed $9.4 \times 10^{8}$ colonies $\mathrm{ml}^{-1}$ and had a germination rate of $130 \% \mathrm{~min}^{-1}$.

\begin{tabular}{|c|c|c|c|c|c|c|}
\hline \multirow[b]{2}{*}{ Cation added } & \multicolumn{2}{|c|}{ Colony formation $(\%)$} & \multicolumn{2}{|c|}{ 'Ala +' } & \multicolumn{2}{|c|}{ 'Ala' } \\
\hline & Untreated & $\mathrm{H}_{2} \mathrm{O}_{2}$ treated & Untreated & $\mathrm{H}_{2} \mathrm{O}_{2}$ treated & Untreated & $\mathrm{H}_{2} \mathrm{O}_{2}$ treated \\
\hline None & 100 & 87 & 100 & $8 \mathrm{I}$ & $3 \cdot 2$ & 56 \\
\hline $\mathrm{Cu}^{2+}$ & 95 & 0.028 & IOI & $7 \cdot 6$ & $4 \cdot 4$ & $6 \cdot 2$ \\
\hline $\mathrm{Fe}^{2+}$ & 72 & 48 & 106 & 66 & 4.8 & 57 \\
\hline $\mathrm{Ni}^{2+}$ & II3 & 63 & $9 I$ & 77 & $3 \cdot 2$ & 57 \\
\hline $\mathrm{Co}^{2+}$ & 98 & 68 & 90 & 34 & $2 \cdot I$ & 24 \\
\hline $\mathrm{Zn}^{2+}$ & I 8 & 88 & 97 & 69 & 0.9 & $3 \cdot I$ \\
\hline
\end{tabular}

Table 2. Effect of $\mathrm{Cu}^{2+}$ and acid washing on the action of hydrogen peroxide

Spores $\left(0.7 \mathrm{mg}\right.$ dry wt $\mathrm{ml}^{-1}$ ) were pre-incubated with $\mathrm{Cu}^{2+}$ for $5 \mathrm{~min}$ at $37^{\circ} \mathrm{C}$, as described in Table $\mathrm{I}$, and then washed (at $0.15 \mathrm{mg}$ dry wt $\mathrm{ml}^{-1}$ ) either with $0.04 \mathrm{M}-\mathrm{HCl}$ followed by two washes with glass-distilled water at $4{ }^{\circ} \mathrm{C}$, or with glass-distilled water alone, before treatment with $0 \cdot 142 \mathrm{M}-\mathrm{H}_{2} \mathrm{O}_{2}$ for $5 \mathrm{~min}$ at $70^{\circ} \mathrm{C}$, as described in Methods. Colony-forming ability and germination rate were measured, the values obtained with the 'Ala +' system from spores pre-incubated without $\mathrm{Cu}^{2+}$ and washed twice with glass-distilled water before $\mathrm{H}_{2} \mathrm{O}_{2}$ treatment being taken as $100 \%$. Such spores formed $5.8 \times 10^{8}$ colonies $\mathrm{ml}^{-1}$ and germinated at a rate of $130 \% \mathrm{~min}^{-1}$. Untreated spores formed $\mathrm{I} \cdot 09 \times 10^{9}$ colonies $\mathrm{ml}^{-1}$ and germinated at a rate of $126 \% \mathrm{~min}^{-1}$.

$\mathrm{Cu}^{2+}$
concn
added
$(\mu \mathrm{M})$
0
5
10

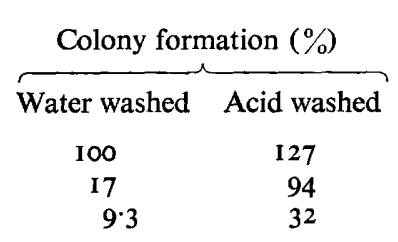

\begin{tabular}{|c|c|c|c|}
\hline \multicolumn{4}{|c|}{ Germination rate $(\%)$} \\
\hline \multicolumn{2}{|c|}{ 'Ala +' } & \multicolumn{2}{|c|}{ 'Ala' } \\
\hline Water washed & Acid washed & Water washed & Acid washed \\
\hline 100 & 90 & 85 & 82 \\
\hline 48 & 73 & 43 & 80 \\
\hline 33 & 85 & 34 & 84 \\
\hline
\end{tabular}

at $70{ }^{\circ} \mathrm{C}$ for $5 \mathrm{~min}$. Similar changes in refractility occurred with $8.5 \mathrm{M}-\mathrm{H}_{2} \mathrm{O}_{2}$ at $25{ }^{\circ} \mathrm{C}$ for $9 \mathrm{~h}$ (Waites et al., 1976), suggesting that in the presence of $\mathrm{Cu}^{2+}$ less severe treatment is required to cause refractility changes.

Dithiothreitol removes protein from spore coats without affecting colony formation (Aronson \& Fitz-James, I97I). We have shown previously that pretreatment of spores with dithiothreitol markedly increases the lethal effect of chlorine on spores (Wyatt \& Waites, 1975). Such pretreatment also increased the lethal effect of $\mathrm{H}_{2} \mathrm{O}_{2}$. Treatment with dithiothreitol, as described in Methods, followed by $\mathrm{I} \cdot 42 \mathrm{M}-\mathrm{H}_{2} \mathrm{O}_{2}$ reduced the fraction of spores able to form colonies to $0.082 \%$ (the colonies formed from untreated spores being taken as $100 \%$ ) compared with reduction to $93 \%$ for treatment with $\mathrm{H}_{2} \mathrm{O}_{2}$ alone and to $40 \%$ for dithiothreitol alone. 


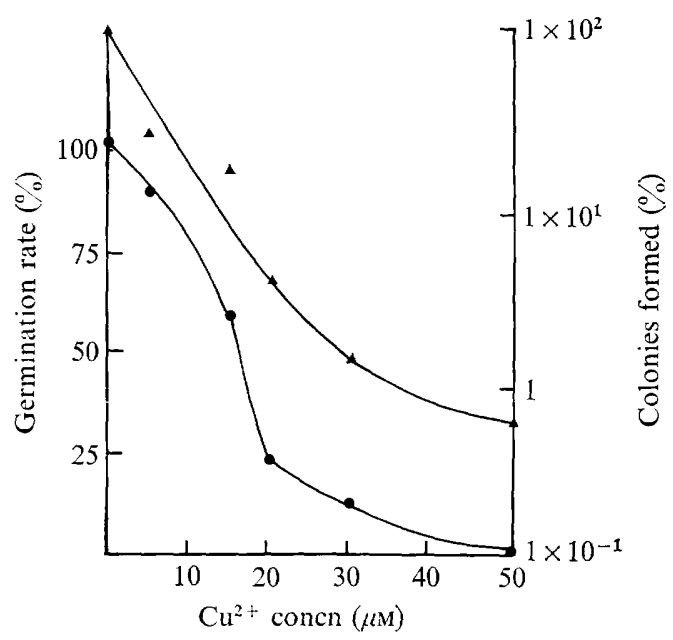

Fig. 4. Effect of $\mathrm{Cu}^{2+}$ concentration on activity of $\mathrm{H}_{2} \mathrm{O}_{2}$. Spores were incubated, as for Fig. 2, with $0.142 \mathrm{M}-\mathrm{H}_{2} \mathrm{O}_{2}$ for $5 \mathrm{~min}$ at $70^{\circ} \mathrm{C}$ in the presence of different concentrations of $\mathrm{Cu}^{2+}$, as described in Methods. Colony-forming ability $(\mathbf{A})$ and germination rates with the 'Ala + ' system $(\boldsymbol{O})$ were determined as for Fig. 2. Results are expressed as a percentage of colonies formed and the germination rate produced by spores treated with $\mathrm{H}_{2} \mathrm{O}_{2}$ in the absence of $\mathrm{Cu}^{2+}$. Such a control formed $1.03 \times 10^{7}$ colonies $\mathrm{ml}^{-1}$, and the germination rate was $74 \% \mathrm{~min}^{-1}$; spores incubated in the absence of $\mathrm{H}_{2} \mathrm{O}_{2}$ formed $7.2 \times 10^{8}$ colonies $\mathrm{ml}^{-1}$ and germinated at a rate of $135 \% \mathrm{~min}^{-1}$.

\section{DISCUSSION}

We have shown that $\mathrm{H}_{2} \mathrm{O}_{2}$ prevents colony formation by spores of Clostridium bifermentans but that most of the spores that could not form colonies were still able to germinate. Such spores are therefore unable to form colonies because they cannot outgrow or divide. Similar results were obtained after treatment of spores with chlorine (Wyatt \& Waites, 1975). The effect of $\mathrm{H}_{2} \mathrm{O}_{2}$ on germination was greatest at $\mathrm{pH} \mathrm{6.7.} \mathrm{With} \mathrm{spores} \mathrm{of} \mathrm{Bacillus}$ sp., Curran et al. (1940) found that inactivation was greatest at $\mathrm{pH} 3 \cdot 0$ but Cerf \& Hermier (1972) found that inactivation at $\mathrm{pH} 6.7$ was more rapid than at $\mathrm{pH} 4.6$ or 7.7 . In this study, as in others (Curran et al., 1940; Roundy, 1958; Swartling \& Lindgren, 1968; Cerf \& Hermier, 1972; Toledo, Escher \& Ayres, 1973), it is apparent that the lethal effect of $\mathrm{H}_{2} \mathrm{O}_{2}$ increases with increasing concentration and temperature. There was a lag during the first minutes of treatment and a later reduced rate of kill, as observed previously (Cerf \& Hermier, 1972). Treatment with $\mathrm{H}_{2} \mathrm{O}_{2}$ makes spores more sensitive to heat (Toledo et al., 1973) so heat may be the major cause of death during this latter phase.

No previous studies have been made on the effect of $\mathrm{H}_{2} \mathrm{O}_{2}$ on spore germination. Our work has shown that germination with suboptimal concentrations of germinants was stimulated more than 25 -fold by mild treatment with $\mathrm{H}_{2} \mathrm{O}_{2}$. Other oxidizing agents such as sodium perborate (Cochran \& Ordal, 1973) and chlorine (Wyatt \& Waites, 1973) also increase the germination rate of spores. Chlorine acts by removing protein, probably from spore coats, and increasing the permeability of the spores to germinants (Wyatt \& Waites, 1975). We have shown that $\mathrm{H}_{2} \mathrm{O}_{2}$ removes a similar protein from spores, which suggests that $\mathrm{H}_{2} \mathrm{O}_{2}$ and chlorine act in the same way. Dithiothreitol also removes protein from spore coats (Aronson \& Fitz-James, 1971), and we have shown that pretreatment of spores with dithiothreitol increased the lethal effect of $\mathrm{H}_{2} \mathrm{O}_{2}$ 500-fold, suggesting that the coat protects spores against $\mathrm{H}_{2} \mathrm{O}_{2}$. A similar conclusion was reached for the effect of chlorine on spores (Wyatt \& Waites, 1975). 
The lethal effect of $\mathrm{H}_{2} \mathrm{O}_{2}$ was increased 3000 -fold by the presence of $100 \mu \mathrm{M}-\mathrm{Cu}^{2+}$. Preincubation with $\mathrm{Cu}^{2+}$ for as little as I min also increased the lethal effect of $\mathrm{H}_{2} \mathrm{O}_{2}$, which suggests that spores absorbed the ions very rapidly. Washing with dilute acid or EDTA, but not glass-distilled water, eliminated the effect of $\mathrm{Cu}^{2+}$, presumably by removing the ions from the spores. Thus the presence of $\mathrm{Cu}^{2+}$ or, to a much lesser extent, $\mathrm{Fe}^{2+}$, during or after spore formation, largely determines the sensitivity of spores of C. bifermentans to $\mathrm{H}_{2} \mathrm{O}_{2}$. Similarly, washing with dilute acid to remove metal precipitates from spore preparations (Slepecky \& Foster, 1959) may increase resistance. $\mathrm{Cu}^{2+}$ increases the rate of breakdown of $\mathrm{H}_{2} \mathrm{O}_{2}$ (Walton \& Graham, 1928) and the rate of cleavage of peptide bonds by $\mathrm{H}_{2} \mathrm{O}_{2}$, and, since most bonds seem to be sensitive (Deasy, 1967), the effect on the spore is likely to be a general destruction of protein.

We are grateful to Dr J. L. Peel for useful discussions and Miss Linda J. Nockolds for skilled technical assistance.

\section{REFERENCES}

Aronson, A. I. \& Fitz-JAmes, P. C. (I97I). Reconstitution of bacterial spore coat layers in vitro. Journal of Bacteriology 108, 571-578.

Cerf, O. \& Hermier, J. (I972). Diversité de la résistance des spores de Bacillus à l'eau oxygénée. Lait 52 , I-20.

Cochran, S. A. \& Ordal, Z. J. (I973). Oxidative activation of Bacillus cereus spores. Applied Microbiology 25, $173-179$.

Curran, H. R., Evans, F. R. \& Leviton, A. (1940). The sporicidal action of hydrogen peroxide and the use of crystalline catalase to dissipate residual peroxide. Journal of Bacteriology 40, 423-434.

DAvis, B. J. \& ORNSTEIN, L. (196I). Disc Electrophoresis. Rochester, U.S.A. : Distillation Products Industries.

DEASY, C. L. (1967). Degradation of collagen by metal ion-hydrogen peroxide systems. I. Evidence for a free radical-catalyzed depolymerization mechanism. Journal of the American Leather Chemists' Association 63, 258-269.

Dittmar, H. R., Baldwin, I. L. \& Miller, S. B. (I930). The influence of certain inorganic salts on the germicidal activity of hydrogen peroxide. Journal of Bacteriology 19, 203-2I I.

Gould, G. W. \& Hitchins, A. D. (1963). Sensitization of bacterial spores to lysozyme and to hydrogen peroxide with agents which rupture disulphide bonds. Journal of General Microbiology 33, 413-423.

HiRsCH, A. \& GRINSTED, E. (I954). Methods for the growth and enumeration of anaerobic spore-formers from cheese, with observations on the effect of nisin. Journal of Dairy Research 2r, IOI-I IO.

Lowry, O. H., Rosebrough, N. J., FarR, A. L. \& Randall, R. J. (I95I). Protein measurement with the Folin phenol reagent. Journal of Biological Chemistry 193, 265-275.

Roberts, T. A. \& Hitchins, A. D. (1969). Resistance of spores. In The Bacterial Spore, pp. 6I I-670. Edited by G. W. Gould and A. Hurst. London and New York: Academic Press.

Roundy, Z. D. (1958). Treatment of milk for cheese with hydrogen peroxide. Journal of Dairy Science 4r, I460-I465.

SLEPECKY, R. \& FosTeR, J. W. (1959). Alterations in metal content of spores of Bacillus megaterium and the effect on some spore properties. Journal of Bacteriology 78, I $17-123$.

Swartling, P. \& Lindgren, B. (1968). The sterilizing effect against Bacillus subtilis spores of hydrogen peroxide at different temperatures and concentration. Journal of Dairy Research 35, 423-428.

Toledo, R. T., Escher, F. E. \& AYres, J. C. (1973). Sporicidal properties of hydrogen peroxide against food spoilage organisms. Applied Microbiology 26, 592-597.

WAITES, W. M. \& WYATT, L. R. (1971). Germination of spores of Clostridium bifermentans by certain amino acids, lactate and pyruvate in the presence of sodium or potassium ions. Journal of General Microbiology 67, $215-222$.

WAITES, W. M. \& WyATT, L. R. (I974a). The outgrowth of spores of Clostridium bifermentans. Journal of General Microbiology 84, 235-244.

Watres, W. M. \& WyatT, L. R. (1974 $b$ ). The effect of $\mathrm{pH}$, germinants and temperature on the germination of spores of Clostridium bifermentans. Journal of General Microbiology 80, 253-258.

Waites, W. M., WyatT, L. R., KInG, N. R. \& Bayliss, C. E. (1976). Changes in spores of Clostridium bifermentans caused by treatment with hydrogen peroxide and cations. Journal of General Microbiology 93, 388-396.

Walton, J. H. \& Graham, D. P. (1928). A study of the oxidation of some dicarboxylic acids by hydrogen peroxide in the presence of certain catalysts. Journal of the American Chemical Society 50, I64I-I645.

Wyatt, L. R. \& WaItes, W. M. (1973). The effect of hypochlorite on the germination of spores of Clostridium bifermentans. Journal of General Microbiology 78, 383-385.

Wyatt, L. R. \& WaITES, W. M. (I975). The effect of chlorine on spores of Clostridium bifermentans, Bacillus subtilis and Bacillus cereus. Journal of General Microbiology 89, 337-344. 